\title{
From Privatization to Deindustrialization: \\ Implications of Chinese Rural Industry and the Ownership Debate Revisited
}

\begin{abstract}
This paper examines the evolution of Chinese rural industry since the rural reform in the late 1970s and revisits the debate on the role of ownership. Based on a case study of W county in southern Jiangsu province as well as drawing on national data, the author shows that the community-based market dynamic had been a key factor in the expansion of rural enterprises and that its weakening in recent years has led to the closing of village enterprises and deindustrialization of the countryside. Large-scale land expropriation, sponsored by local government, is the principal factor responsible for the change.
\end{abstract}

Key words: Asia, China, rural enterprise, ownership, land expropriation, community-based market dynamic 


\section{From Privatization to Deindustrialization: \\ Implications of Chinese Rural Industry and the Ownership Debate Revisited}

\section{INTRODUCTION}

Chinese rural industry once presented a puzzle to scholars. Despite their remarkable performance, many of the rural industrial enterprises (called Township \& Village Enterprises or TVEs) were owned collectively with ambiguous ownership. This deviated from a widely-held economic doctrine: private property ownership, specified and protected, is a key determinant to economic growth (North \& Thomas, 1973). The incompatibility between theory and reality triggered a number of studies on TVEs, which debated the causes of their success and the role of ownership. ${ }^{1}$ While this ownership debate ended in the early 2000s with most collective enterprises privatized, the issue was not resolved. ${ }^{2}$

The ownership debate contributed to the literature of economic transition and development. ${ }^{3}$ In addition, it echoed the worldwide concern over ownership in development research and practice during the 1980s and 1990s (Shirley \& Walsh, 2001). However, it also limited the scope of research to ownership-related issues. Indeed, after the process of privatization was largely completed in 2002, academic interest in TVEs quickly faded away. This gave rise to the impression that the only important legacy of Chinese rural industry was its short-lived collective ownership or, to some scholars, the inevitable triumph of private ownership.

This article will revisit the ownership debate by examining both pre- and post-privatization periods. My investigation was guided by two interrelated questions: First, can post-privatization changes offer new insights to the debate? Second, what implications, besides its ownership, can be drawn from the case of Chinese rural industry? I base my analysis on field research in W county in southern Jiangsu province, where TVEs were among the most developed. Within the county, I selected Z village as the site for indepth investigation. ${ }^{4}$ I concentrate on village enterprises including both collective village enterprises and private household enterprises, which are called community enterprises in this paper, though I will also 
bring in township enterprises for comparison. The separation of township and village enterprises is necessary, for the reason I will specify in Section 2.

My research shows that the success of rural enterprises in more than three decades should also be attributed to a community-based market dynamic that combines the advantages of both the market and community. When this condition ceased to exist in recent years, particularly with village land expropriated for urban real estate, $\mathrm{Z}$ village, together with all other villages in the area, had undergone a process of deindustrialization, in which private rural enterprises were forced to shut down.

Deindustrialization in this paper does not mean a complete disappearance of industrial activities, ${ }^{5}$ but is used to highlight the end of rural industrialization, with industrialized villages being turned into urban real estate and the rural population being deprived of industrial jobs and factories.

The community-based market dynamic is a unique combination of two different principles: the community principle that gives enterprises exclusive access to community resources but requires their activities to involve and benefit community members, and the market principle that forces these enterprises to compete on the open market. The first principle lowers production costs for village enterprises and increases community welfare, while the second principle compels these enterprises to improve performance for maintaining market competitiveness.

By highlighting the community-based market dynamic, this study is related to the literature that stresses the importance of community to economic development and livelihood security. Over the past two decades, a large amount of literature has focused on the role of community in social and economic development, particularly in the area of natural resource management (Agrawal \& Gibson, 1999; Agrawal \& Chhatre, 2006; Bardhan, 1993; Ife \& Tesoriero, 2006; Li, 2002; Ostrom, 1990). Contrary to the earlier notion that community presented an obstacle to modernization, the recent literature highlighted the positive features of community such as reciprocity, solidarity and participation. International donors such as the World Bank had also funded a large number of community development projects since the late 1980s (Mansuri \& Rao, 2004; Dasgupta \& Beard, 2007; Fritzen, 2007). Recent studies also called attention to the importance of internal heterogeneity and external institutions in shaping the role of 
community in the process of development, which I will also examine in this study (Agrawal \& Gibson, 1999; Blaikie, 2006; Li, 2002; Gonzalez De La Rocha, 2001; Mansuri \& Rao, 2004).

In addition, scholars have long emphasized the significance of community to poor people's livelihood security. For example, James Scott argued that rural communities in Southeast Asia, to varying degrees, provided "subsistence insurance" through reciprocal community norms, networks and institutions, helping peasants to survive through subsistence crises (Scott, 1976). Writing on a very different context, Gonzalez De La Rocha (1994) showed how poor urban households in Guadalajara, Mexico were able to make use of resources in community settings through social networks and informal organizations. She highlighted the strategies of urban households in their struggle for survival, including combining different sources of income, making collective arrangements and relying on women's contributions.

This paper both builds on and contributes to this literature by showing the important role of community during China's rural industrialization. As I will discuss in detail, Chinese rural enterprises, village enterprises in particular, were built with community resources such as land, labor and social networks. In addition, trust, mutual assistance, household strategy and community norms facilitated economic cooperation within and between enterprises, and placed an additional layer of supervision on the managers of collective enterprises (community elites). Additionally, this study intends to make fresh contributions to the literature in three respects. First, it demonstrates the possibility to harness both community and market forces in the development process, which are usually seen as contradictory (Agrawal \& Gibson, 1999: 630-631; Hayami, 1998). Specifically, I will show that the boundary of community did not hinder but facilitate market competition in the case of Chinese rural industry, and that access to markets benefited rather than hurt community enterprises. Second, this study shows that the role of community is not limited to being a safeguard for subsistence. It could provide conditions for poor people to pursue profitable enterprises and form a powerful economic force. Finally, community enterprises, collective or private in ownership, all highly depend on community resources for survival and success, and few could persist once their community base is removed. 
The rest of the article is organized as follows. Section 2 briefly reviews the ownership debate and discusses the role of community; Section 3 introduces methodology, field site and data collection; Section 4 shows the emergence of the dynamic in the 1980s; Section 5 investigates forces leading to the privatization and their impacts on the dynamic; Section 6 shows how changes in local revenue regime weakened the dynamic and set in motion a process of deindustrialization; Section 7 revisits the ownership debate and discuss the future implications of the weakening of the dynamic; Section 8 concludes.

\section{THE OWNERSHIP DEBATE AND “MISSED” COMMUNITY}

The ownership debate started in the 1980s and ended in 2002 when most collective enterprises were privatized. One camp in the debate advocated private ownership and market institutions, whereas the other underscored the importance of collective ownership and the role of the state. ${ }^{6}$

The rapid expansion of collective enterprises in the early reform period (1980s and early 1990s) directly confronted scholars who advocated private ownership. A common strategy was to attribute it to the external environment, such as the imperfect market and the hostile political atmosphere. For example, Nee (1992: 4, 8-12) pointed out that it was easier for collective enterprises than private ones to obtain credit, factor resources and political protection from the state. ${ }^{7}$ Naughton (1994) argued that collective enterprises offered a feasible way to turn community assets into income when factor markets for land and labor were underdeveloped. This camp of scholars also stressed the importance of free entry, competition and hard budget constraints, which were related to the market (Whiting, 1996; Luo, Tan \& Shenkar, 1998). In addition, most of them considered collective ownership only a temporary feature of Chinese economy (Nee, 1989; Qian, 2000).

By contrast, the other camp argued for positive roles played by collective enterprises and the state. For example, Jean Oi argued that local governments played a crucial role in promoting TVEs, forming a phenomenon called "local state corporatism" (Oi, 1992; 1999). According to her, the fiscal reform in the early 1980s that allowed local governments to retain the bulk of residual revenue, which previously must be turned over to upper-level governments, gave local officials a strong incentive to develop rural 
industry and support collective enterprises. For scholars in this camp, collective ownership was both the proof of an active state and the mechanism through which the state controlled and operated rural enterprises (Walder, 1995).

However, both camps, focusing on the market or state, had paid inadequate attention to village community, which, as I will show below, had been a major factor in the expansion of rural enterprises. Bringing in community raises questions about the ownership-based classification of rural enterprises. For example, township and collective village enterprises were both collective in ownership, but the former were controlled by the government, whereas the latter were the assets of village community. In addition, household enterprises were privately owned, but operating within a community, they highly depended on community resources for success as did collective village enterprises.

The role of community, missed in the ownership debate, brings to light the importance of access to land (and community resources in general) and household strategy, while extending the scope of research beyond ownership. Due to the land reform and collectivization campaigns in the 1950s, land in Chinese villages became collectively owned. This gave villages and households the exclusive right to establish rural enterprises with village land in the 1980s and 1990s. The local government took village land to establish enterprises in this period, but it acknowledged villages' land rights by offering villagers manufacturing jobs. Since the late 1990s, however, the government had started to strip villages of land rights and sell village land to large corporations and developers. This change had greatly affected rural enterprises. In addition, the community perspective highlights the significance of household strategy, which, as Gonzalez De La Rocha (1994) has shown, was an important way for poor households to survive on community resources. During China's rural industrialization, households contributed to the establishment of most rural enterprises. Table 1 shows that household enterprises employed much more rural laborers than collective enterprises and contributed more than a third of rural industrial output in 1996. The community perspective also extends the timeline of Chinese rural industry. After collective enterprises were mostly privatized in 2002, the ownership debate came to an end (Li \& Rozelle, 2003; Chang, McCall \& Wang 2003; Sonobe \& Otsuka, 2004; Oi, 1999: 624). However, while collective 
village enterprises were privatized, other community enterprises, mostly household enterprises, continued to exist and provide a crucial source of income for the local population. Moreover, these enterprises experienced a temporary boom following the privatization thanks to the community-based market dynamic. It was only in the recent decade that they were forced to shut down due to the removal of their community base.

\section{[Table 1 here]}

The following sections will examine the rise and fall of community enterprises, including both collective village and household enterprises, in Chinese rural industry based on the case of W county as well as the experiences of $\mathrm{Z}$ village.

\section{METHODOLOGY, FIELD SITE AND DATA COLLECTION}

$\mathrm{Z}$ village is located within $\mathrm{Y}$ township of $\mathrm{W}$ county of Changzhou prefecture in southern Jiangsu province (Figure 1), ${ }^{8}$ where rural industry was called the "Sunan model." ${ }^{9}$ Southern Jiangsu lies between Shanghai and Nanjing (the capital of Jiangsu province), including three prefectures: Suzhou, Wuxi and Changzhou (Figure 1). This location provided the region with favorable conditions for rural industry: good transportation networks and relatively easy access to urban technology and markets because Shanghai and Nanjing had been two of the most important industrial centers in China for the $20^{\text {th }}$ century. Moreover, there had been a steady stream of migration from the countryside of southern Jiangsu to the two cities in the first half of the $20^{\text {th }}$ century. By the 1960 s, many villages in the area could find former residents working in factories in Shanghai or Nanjing, and some of the workers still had families, relatives and friends in the countryside. These social networks were a valuable resource, through which the villages could gain access to technology and market information.

In the 1960s and 1970s, townships and villages in southern Jiangsu, ${ }^{10}$ as in many other areas, started to establish collective enterprises. On the eve of the reform in 1978, its rural industrial output reached 2.6 
billion yuan, exceeding agricultural output (1.6 billion) by a significant margin (Zhou, ed., 1994: 15). In the 1980s, more collective enterprises were set up in the region, contributing to the bulk of rural industrial output, usually more than 70 percent, and the region became famous for its highly developed rural industry. Scholars singled out southern Jiangsu for its prevalence of collective ownership. However, as I will show below, private household enterprises in the region emerged in the early 1980s and grew rapidly thereafter, a situation that was similar to other regions. In addition, collective ownership was a common feature of Chinese rural industry, though it was the strongest in southern Jiangsu.

\section{[Figure 1 here]}

Nevertheless, the selection of Changzhou was not because it was nationally representative but because it suited the purpose of this study. First, the Sunan model had been at the center of the ownership debate, which is an important theme of this paper. Second, the privatization in Changzhou had closely followed the national trend in the 1990s and early 2000s. Finally, its highly developed rural industry allows me to show the roles of ownership, community, the state, and the market in rural industrialization.

$\mathrm{Z}$ village is a typical village in southern Jiangsu in terms of resource endowment. Its land-to-population ratio was extremely low. In 1977, the village's 1,495 people relied on 1,075 mu of farmland (15 mu equals one ha.), only $0.72 \mathrm{mu}$ (about 0.05 ha.) per person. This was a general situation in southern Jiangsu (Zhou, ed., 1994: 4). Such a small amount of land limited agricultural income, forcing peasants to engage in nonfarm activities since the $18^{\text {th }}$ century, if not earlier (Huang, 1990; Li, 2000). In Z and other villages of Y township, the main nonfarm activity before 1949 was cloth making. ${ }^{11}$ According to Z village's gazetteer, about one third of households owned weaving looms in the early 1950s. The government organized these households into cooperatives in the 1950s, which became collective textile factories in the 1970s. This was also a nation-wide phenomenon as the state sought to collectivize handicraft activities.

Z village established its first factory in 1963 producing metal plates for machines, with the help of a technician in Shanghai, whose family resided in $\mathrm{Z}$ village but migrated to Shanghai in the early $20^{\text {th }}$ 
century. After that, Z village established three small factories in the 1970s and another three in the 1980s. By the early 1980s, rural industry had become an important source of household income. In 1982, there were 496 people working in TVEs, making up more than a half of its labor force (about 900 people). Women contributed at least 40 percent of the industrial labor force because many local TVEs were textile factories that employed women in production lines. This was important to later development because skilled women played a crucial role in setting up household textile factories.

As early as the mid-1980s, households in $\mathrm{Z}$ village started to establish factories, and their number had been growing until recently. By the time of my fieldwork in 2010, there were 135 industrial enterprises and 2,432 industrial workers in the village. Except for a few relatively large enterprises (employing 50 workers or more), most of them were small household enterprises, employing fewer than 20 workers. The majority of household enterprises were textile factories, but a small number were manufacturing other products such as plastics, electric motors, machine parts and shoe accessories. About 60 percent of the households in the village did not own an enterprise, and their members usually worked for local enterprises as managers or technicians. It was rare for them to take up manufacturing work, which was now performed by migrant workers.

$\mathrm{Z}$ village's local population remained around 1,500 in the past three decades, but migrants started to arrive in the mid-1990s, and its number grew rapidly in the 2000s. In 2010, the migratory population reached about 3,000. The majority of migrants were female, operating power looms in textile factories, a job that belonged to local women in the 1980s and 1990s. Although many of them lived in the village, they were socially segregated as they rarely participated in village-organized public activities or built lasting social ties with local people. Migrant workers were sensitive to changes in the labor market and life cycles, and few migrant workers in $\mathrm{Z}$ village had stayed longer than 10 years: they migrated elsewhere or went back to their hometowns.

What guided my fieldwork in W county can be called the extended case study method. ${ }^{12}$ I started investigation in $\mathrm{Z}$ village. However, changes within the village were often caused by forces outside. To understand these forces, I extended my investigation beyond the village boundary to a larger geographical 
area to include $\mathrm{W}$ county and even Changzhou prefecture. In addition, I also examined how these local changes were related to national conditions. External forces I investigated included state policy and market conditions.

State policy took effect through a hierarchy of governments: central, provincial, prefectural, county and township. The upper level government issues policy guidelines, and the lower level government works out implementation plans. However, the lower level government often adds or drops some policy elements during policy implementation. Therefore, one cannot exactly know how a policy is implemented only by reading policy documents. The township is the lowest level of government, but there are also government-like institutions at the village level: (communist) party branch and village committee, which are supposed to report village affairs to the government and implement government policy. However, village officials not always act as the agents of the state, but often negotiate with the state for the interest of the village community, to which they are also members. Rural enterprises in China have been highly involved in market exchange. Markets examined in this study include those for manufacturing goods, land and labor.

I made three field trips to W county between August 2010 and January 2011, and each trip lasted about one month. Prior to my fieldwork, I went through unpublished ethnographic data collected by my local collaborator, who was a university teacher in Nanjing and had made at least five field trips to $\mathrm{Z}$ village since 1996. Her data provided prior knowledge that helped me design this study. My first trip started in late August. During this trip I interviewed village officials for basic information and its history of rural industry. After that, I selected different types of households for interviews: households whose members worked for collective enterprises; households that were running small factories; households whose members were working for private enterprises; and others. I also diversified interviewees based on industry (textile, machinery, plastic modeling, etc.), income level (high, middle and low), age and gender. Within a household, I interviewed either husband or wife, or both. Men were usually household heads and default interviewees when I went to visit a household. Thus I asked to interview women whenever possible. Among all interviewees, one third was female. Meanwhile, I spent a great deal of time going 
through a large stock of village archives, which collected all important documents of the village since the 1970s including records of rural enterprises, population censuses, employment files, minutes of village meetings, policy implementation plans, dispute settlements, etc. During my field trips, I lived in a small hotel within walking distance to the village. I made participant observation of village life and visited dozens of households, workers' dormitories, migrant workers' houses, factories, health clinics, schools and grocery markets. In late September, I retreated from the field and conducted preliminary analysis of collected data, based on which I planned the second field trip in mid-October. In addition to conducting more household interviews, the second field trip extended my investigation to Y township and further to W county. I went to both levels of government to collect policy documents and official statistics on rural industry. In addition, I interviewed six officials (three officials at each level) for their opinions on local industry and economy in general. I also interviewed six migrant workers/families who lived or worked in $\mathrm{Z}$ village. All my interviews added up to 62 in total. My third trip started in early December. In addition to collecting more data on $\mathrm{Z}$ village, $\mathrm{Y}$ township and $\mathrm{W}$ county, I visited the neighboring areas of $\mathrm{Z}$ village and visited three enterprises that were relocated due to land expropriation. In addition, I visited three large industrial parks in Changzhou prefecture, and made the observation of on-going rapid urbanization in the city. Another source of information was local online forums where local residents anonymously expressed their opinions of local events. ${ }^{13}$

\section{EMERGENCE OF THE COMMUNITY-BASED MARKET DYNAMIC}

The Mao period (1949-1976) laid a solid foundation for rural industry (Putterman, 1997). ${ }^{14}$ By restricting both the market and household, however, the collective period had not fully released the potential of community-based growth. The reform opened up markets and permitted rural households to engage in private business. As a result, a new force, which I call "community-based market dynamic", emerged to drive the further growth of rural industry. This section examines the formation of the dynamic in the 1980s and its effects on both collective and private enterprises. 


\section{(a) Rise of household as an independent economic unit}

The dynamic came into being not only because of the policies opening up markets but also those empowering households. During the Mao period, households had little autonomy, and it was collectives that decided all important matters. This started to change after the reform. First, households became the primary decision maker on farming under the Household Responsibility System, which replaced collective farming (Dong, 1996). In Z village, rural residents started to reduce labor on grain crops and engage in more profitable activities, though they still farmed land for food. ${ }^{15}$ Some of them grew cash crops, opened small shops, or took up sideline activities such as tailoring, carpentering and truck driving. A growing number of households established small factories, among which many were textile factories. The village archives recorded about 20 such workshops in 1990. These workshops were small in scale, owning several looms and employing only family members or relatives. In W county, household enterprises grew 62.6 percent a year between 1980 and 1985, twice as fast as collective enterprises. ${ }^{16}$

A key factor to the success of household enterprises was household strategy. As Gonzalez De La Rocha (1994) showed, household strategies such as combining different economic activities, strategizing the use of family labor and relying on women's contributions allow poor households to allocate household resources and draw on community resources effectively. Similar strategies were adopted by Chinese rural households. In $\mathrm{Z}$ village, households usually combined industrial and agricultural activities in the 1980s. They worked in factories to earn relatively high income while farming land for self-consumption. In addition, an increasing number of households started private enterprises while keeping jobs in collective enterprises. Usually, the husband worked in a collective enterprise and took care of the enterprise after work, and the wife managed everyday enterprise and household matters. If it were an extended family, the division of labor would be more complicated but follow the same rule, that is, some members took up wage employment while others took care of the enterprise and household. This was dubbed "one family, two systems" (yijia liangzhi) in W county. ${ }^{17}$ However, the reason for starting a small enterprise was not that wages were insufficient to support a household, as Gonzalez De La Rocha found in her case, but that a private enterprise generated more income than wage jobs in collective enterprises. 
It was not easy to start an enterprise because it required at least start-up investment, business skills and access to trade networks. My fieldwork found that it was collective enterprises that provided these conditions. The arrangement of "one family, two systems" allowed household enterprises to use skills that their members learned from collective enterprises, to produce for the latter and to market through their trade networks. That is to say, collective enterprises provided important community resources that households could exploit. Mr. Zhang Changyi, born and growing up in the village, had been the accountant of $Z$ village for more than 30 years since the late 1970s, and was very familiar with the history industrial development in the village. He called collective enterprises in the 1980s and 1990s "training schools" for household enterprises, and asserted that the latter highly depended on the former. ${ }^{18}$ The use of household strategy also benefited collective enterprises because household activities provided their workers with food, housing and supplemental income so that collective enterprises could pay them at lower rates of wages. ${ }^{19}$ It was found that low production costs including low wage rates were an important advantage of rural enterprises (eg. Byrd \& Lin, eds., 1990).

Thus households (including household enterprises) and collective enterprises formed a symbiotic relationship, in which they depended on each other for success. This mutual dependence in southern Jiangsu and elsewhere has been overlooked by most scholars involved in the ownership debate, who pit one against the other for their difference in ownership.

Household strategy was an important part of the community-based market dynamic. However, it could not explain the formation and distribution of community resources, which was crucial for the success of community enterprises. To understand it, we must turn to the dual principles of the dynamic — community and market principles.

\section{(b) Community and market principles}

As noted earlier, the community principle gives community enterprises exclusive access to community resources while at the same time requiring them to involve and benefit community members. ${ }^{20}$ The market principle forces enterprises to compete in the market. 


\section{The community principle}

The condition of exclusive access to community resources, particularly land, is often difficult to meet due to state intervention, intrusion of outsiders such as large corporations, and power relations within community that concentrate resources in the hands of elites (Agrawal \& Gibson, 1999; Mansuri \& Rao, 2004; Dasgupta \& Beard, 2007). The land reform and collectivization campaigns in the 1950s provided Chinese villages with this condition: village land had become collectively owned and rural households had relatively equal access to the usage rights of land within the village (Dong, 1994; Pei, 2002). This was the situation in the 1980s and early 1990s. Afterwards, multiple actors including the state, private companies from outside and rich households sought to control village land. Until the recent decade, however, a large number of households still had the right of access to land in their villages, including rural migrants who worked in the city (Zhan, 2011).

In the 1980s, community enterprises relied on village land to establish factories. All six collective enterprises of $\mathrm{Z}$ village were built within the village, whereas rural households turned parts of their own houses into factories. ${ }^{21}$ Township enterprises obtained land through the township government, which usually took land from villages within its jurisdiction. In the 1980s and 1990s, the government must offer employment in township enterprises in return when it took village land. In addition, it was rare that the government would expropriate a large piece of land from a single village. This allowed the village to maintain the control of most of its land. Access to land helped community enterprises save on rents and provided their workers with food, water, housing and other daily necessities, thus lowering the cost of production.

Another community resource is labor. In the 1980s and early 1990s, community enterprises mainly hired rural laborers in the village. Within the community context, labor costs were lowered through a combination of the effective use of resources and household strategy. On the one hand, rural workers tended to perform multiple tasks. For example, it was common that they worked both in the factory and on the farm. Within a factory, household enterprise in particular, a worker would take up multiple tasks 
such as managing, accounting and purchasing. Women often played multiple roles in enterprise management and household matters. On the other hand, rural enterprises were able to use semi-labor including the elderly, the weak and the unskilled in the village community. Labor multifunctionality and the use of semi-labor allowed community enterprises maximized the use of community labor. ${ }^{22}$ Since the mid-1990s, village enterprises in W county started to employ migrant labor, but community labor continued to be important. In contrast, while township enterprises were also able to employ low-cost village labor, they usually could not take advantage of semi-labor and labor multifunctionality.

The third resource is community-based social networks, which can be classified into external and internal networks (Mansuri \& Rao, 2004; Portes \& Landolt, 2000; Woolcock \& Narayan, 2000). Both networks were important to community enterprises in southern Jiangsu. As noted earlier, the first factory in $\mathrm{Z}$ village was built with the help of a Shanghai technician, whose family had lived in the village. Mr. Wu Wenxin, born in 1954, started to work for collective village enterprises in 1968. He was one of the pioneers who helped build the collective shoe accessory factory in $\mathrm{Z}$ village, and worked for the factory until 2003 after it was privatized. He and his wife then started a small textile factory, but it lasted only a year due to mismanagement and market competition. He worked as a security guard when I interviewed him. He told me that he went with fellow villagers to Shanghai and Nanjing innumerable times in the 1970s and 1980s to seek technology and markets. The people who they looked for first were those who had ties with households in $\mathrm{Z}$ village, and asked them to introduce others if they were not able to help. These ties were crucial for the establishment and success of the shoe accessory factory. ${ }^{23}$

Internal networks within the village were usually associated with kinship and long-term common residence. Research has found that these networks, or called social capital, mattered a great deal to the success of rural enterprises in China (Liu, 1995; Peng, 2004). Z village was formed in the middle $19^{\text {th }}$ century, and had existed for more than 150 years by the time of my fieldwork. Such a long history of common residence generated intense intra-community networks. When I was in the village, I observed frequent social interactions between households and a high level of familiarity as they knew each other's situations such as household members, income level, occupation, and kinship ties. Trust within the 
community and social networks helped the success of community enterprises. In $\mathrm{Z}$ village, all household enterprises used family members, relatives and fellow villagers as the core labor force. In addition, these enterprises also accessed through social networks a range of resources such as loans, technology and market information. This is a finding captured by other studies, ${ }^{24}$ and I will not elaborate here due to space limit. I want to emphasize that intra-community networks also played a key role in supervising the managers of collective village enterprises. Residing in the village and socializing through its networks, the managers must consider community opinions if they attempt corruption. This is where collective village enterprises departed from township enterprises since the latter mainly relied on the government to supervise managers. When government supervision weakened in the 1990s, the managers of township enterprises started to embezzle collective assets.

\section{The market principle}

The market principle places village enterprises under the pressure of competition, forcing them to improve performance. According to previous research, market competition was highly intense in the 1980s (Bryd \& Zhu, 1990). My fieldwork in W county found the same. In response to market competition, $\mathrm{Z}$ village introduced the responsibility system in collective enterprises as early as 1983 and associated one's material rewards with contributions. This was a common practice in southern Jiangsu and in many other areas (Whiting, 1996).

However, the market principle did not produce "free" markets because the community boundary prevented factors of production such as land and labor from being completely marketized. As noted earlier, village land was collectively owned and access to land was first granted to village residents. Community enterprises also first hired local laborers within the village. In other words, the village boundary provided a shield for enterprises and laborers, protecting them from, to a certain degree, forces in the factor market but nonetheless subjecting them to competition in the product market.

The existence of the community boundary did not obstruct but facilitate competition because it prevented enterprises from being taken over by those in another community or large corporations from 
elsewhere. In other words, market competition could drive individual community enterprises out of business but cannot eliminate them as a whole. If one enterprise failed, rural residents in the village would replace it with another. ${ }^{25}$ The persistence of community enterprises increased the intensity of market competition by keeping a large number of competitors in the market. In addition, competition took place between villages, which was facilitated by the local government. According to Mr. Pan Yuanfang, the party secretary of $\mathrm{Z}$ village, government-sponsored meetings and training programs introduced and promoted the best practices, and their subsequent dissemination among villages further increased inter-

village competition. ${ }^{26}$ Inter-village competition was sometimes considered negative in official reports and scholarly research. It was dubbed "every village lights up a fire, and every household sets off smoke" (cuncun dianhuo, huhu maoyan), suggesting a chaotic competitive situation (Ye, Zhang \& Wu, 1995). However, it was this type of competition that drove the rapid expansion of rural enterprises in southern Jiangsu and elsewhere in the early reform period.

The emergence of the dynamic owed much to state policies in the $1980 \mathrm{~s}$, which protected villages and households' access to land, provided credit for collective enterprises, and offered technological support. ${ }^{27}$ However, this started to change in the $1990 \mathrm{~s}^{28}$

\section{DISMANTLING COLLECTIVE ENTERPRISES}

The 1990s saw radical changes in both state policy and market conditions. The central policy after 1993 shifted from pro-rural to pro-urban, and became increasingly hostile toward public ownership (Huang, 2008). The market also underwent significant changes. With the support of the Chinese state, industrial production became increasingly export-oriented, and foreign and urban capital started moving into the countryside. This section examines how these changes affected rural enterprises and the community-based market dynamic. My research found that, first, driven by the dynamic, private enterprises, most of them household enterprises, continued to grow rapidly; second, collective enterprises declined in the 1990s under the combined impacts of expansion of private enterprises, weakening control 
of TVE managers and hostile state policy; third, collective village enterprises, protected and supported by the dynamic, performed better than township enterprises.

As noted earlier, many scholars attributed the decline of collective enterprises in the 1990s to their ownership. My research shows that it was a result of multiple forces, however. First, the expansion of private enterprises took a toll on collective enterprises. Y township's statistics showed that the number of private industrial enterprises reached 849 in $1998,{ }^{29}$ producing half of the total industrial output. In the service sector, there were more than 3,000 private enterprises, taking up two thirds of the market. The expansion of private enterprises was also a national trend in the 1990s (Figure 2). This increased competitive pressure on collective enterprises, and in the meantime drained their resources as an increasing number of talented workers left collective enterprises to set up their own enterprises. In the 1980s, however, these workers had tended to stay because private enterprises they set up were weak and depended much on collective enterprises for success and even survival.

[Figure 2 here]

Additionally, large urban and foreign capital started to establish new factories in the countryside or take over existing ones in the 1990s. This further increased competitive pressure on collective enterprises. Foreign capital (including capital from Hong Kong and Taiwan) expanded rapidly in the area. The number of foreign-invested enterprises in W county had surged from 18 to 1,013 in the 1990s, and foreign capital accounted for as much as 20 percent of industrial investment between 1999 and $2001 .{ }^{30}$

Second, the managers of collective enterprises started to pursue self-interest at the expense of collective enterprises. While the county and township governments were able to supervise and motivate them for collective interest in the 1980s, it became increasingly difficult in the 1990s, due both to the weakening of supervising capacity and the rising power of the managers (Kung \& Lin, 2007; Zhang, 2005; Zhang \& Yuan, 2003). Many of these managers or their families set up private enterprises as an avenue to 
embezzle collective resources. A 1993 government document of W county discussed the seriousness of the problem.

"It is common that collective assets and know-how have fallen into private hands. A system that can effectively supervise and monitor TVE managers is absent. In addition, the problem that the managers are playing two roles (the manager of collective enterprise and the actual owner of private enterprise) has become increasingly serious. Many managers' families, relatives and friends are engaged in trade or running industrial enterprises that parasitize on collective enterprises, leading the latter to be inefficient and suffer visible or invisible losses." 31

For various reasons, local governments in the 1990s increased extra charges on township enterprises (Zhang \& Yuan, 2003). Partly as a response, these enterprises took loans from government-controlled banks with no plan of paying back. By the late 1990s, many township enterprises were in a high level of debt, and some even running under deficit (Park \& Shen, 2003; Lu, 2000).

Third, the central government became hostile toward public ownership after the Third Plenary Session of the $14^{\text {th }}$ Central Committee in 1993, which announced to establish a "pure" market economy. This was different from the 1980s when it allowed a "mixed" form of economy. Local governments obviously felt the change of political wind. As early as 1994, W county started to prepare for ownership reform, and emphasized the importance of ownership reform every year thereafter.

However, collective village enterprises performed better than township enterprises. In 1997, 23.4 percent of township enterprises in W county were running in red, as compared with only six percent of collective village enterprises. ${ }^{32}$ Nationally, 9.8 percent of township enterprises suffered losses in 1996, compared with only 4.4 percent of collective village enterprises (MOAC, 1997: 121). The difference was derived from the community-based market dynamic that counteracted some negative impacts. First, community supervision on collective village enterprises reduced the likelihood of management corruption. It is not to say that the managers would not attempt corruption. In $\mathrm{Z}$ village, the village textile factory was closed in 1997 because its manager set up his own factory elsewhere and embezzled, to which he diverted collective resources. However, corrupt managers would face public censure in the village. Probably to 
avoid this, the manager moved out of $\mathrm{Z}$ village after the factory was closed. It should be pointed out that there was wide variation among villages: some villages were more tight-knit and cohesive than others, and thus would better supervise their managers.

In addition, the village boundary protected community enterprises from the impacts of adverse market forces and the predatory government. These enterprises depended on community resources such as land, labor and social resources that were usually unavailable for new competitors. In addition, they were largely independent of the local government economically except that they had to pay taxes. Their township counterparts, however, did not have the advantage of community resources and had to compete head to head with powerful competitors from outside. Moreover, they were controlled by the government and prone to its predatory behavior. ${ }^{33}$

The importance of the dynamic in the 1990s was also demonstrated by the rapid growth of household enterprises. In Z village, 89 households owned nonfarm enterprises in 1996, and more than 30 households were running small textile factories. Figure 2 above also showed it was also a national trend.

The expansion of private enterprises including household enterprises increased demand for land for building factories. In the 1980s, local governments and village authorities usually provided land for collective enterprises. In the mid-1990s, however, they started to lease out land for private enterprises. This became increasingly profitable as demand shot up. The price for one mu of land in $\mathrm{Z}$ village increased from 13 thousand yuan in 1994 to 33 thousand in 1999 (one US dollar equaled approximately 8.3 yuan in the 1990 s and early 2000s). ${ }^{34}$ The emergence of this new source of revenue affected later changes in rural enterprises. It opened up the possibility for outsiders including large corporations to control land in the village community, though land was still first granted to households within in the 1990s. In addition, this new source of revenue extricated local governments from relying on collective enterprises, thus paving the way for privatization.

Approved and even encouraged by the central government, Jiangsu province, and many other regions as well, started to privatize all collective enterprises in 1999. It sold collective enterprises to incumbent managers at evaluated prices and compensated workers with a small amount of money. ${ }^{35}$ 
In summary, it was not (only) the underperformance of collective enterprises that led to the privatization. Rather, it was politico-economic forces surfaced in the 1990s that led the Chinese state to dismantle collective enterprises. These forces had not yet seriously affected the community-based market dynamic in the 1990s, but they signaled the direction of change in the 2000s.

\section{DEINDUSTRIALIZATION AND THE WEAKENED DYNAMIC}

This section examines post-privatization changes in W county. Household enterprises experienced a boom after privatization thanks to the community-based market dynamic. However, the boom did not last long as local governments accelerated land grab for revenue. Meanwhile, more and more large private enterprises moved to the countryside and sought to control production and trade networks, squeezing the space of community enterprises. These changes undermined the dynamic, resulting in massive closedowns of community enterprises. Industrialized villages such as $\mathrm{Z}$ village thus underwent a process of deindustrialization.

Community enterprises did not disappear after collective enterprises were privatized. Rather, it prospered in the form of household enterprise in the early 2000s. The number of small factories in Z village increased from 65 in 1999 to 177 in 2006. Y township added 798 industrial enterprises between 2001 and 2004, of which 726 were household enterprises. ${ }^{36}$ The community-based market dynamic was the main factor behind the boom. Access to village land and labor, plus technical know-how, credit and trade networks, which were associated with prior experiences in collective enterprises and community social networks, allowed former collective workers to start private enterprises after they lost job security and shares in collective enterprise.

A crucial condition was access to village land. In 2000, the township government enclosed 110 mu of farmland in $\mathrm{Z}$ village, and leased it out to private enterprises. Such a large-scale enclosure alarmed $\mathrm{Z}$ village's authority, which predicted that the government would grab the rest of the land if it did not act. Thus $\mathrm{Z}$ village sold or rented most of its land to rural households in the village for building factories. Mr. Pan Yuanfang, the party secretary of $Z$ village, was a politically shrewd and far-sighted man. Pan, 57 
years old, born and growing up in the village, became the party secretary in 1990 and had maintained the position ever since. He told me that all villages in $\mathrm{W}$ county were not as lucky as $\mathrm{Z}$ village, and that some villages lost a large chunk of land to the government in the early 2000s, suggesting that the struggle for land between the government and villages started to intensify. ${ }^{37}$

The boom also depended on the availability of cheap migrant labor. In 2006, the village hired about 3,000 migrant workers, twice as much as the village's population. Relying excessively on migrant labor increased the vulnerability of household enterprises because they had to compete with large enterprises for this labor source. It posed no problem when migrant labor was in abundant supply. After 2006, however, migrant labor became in shortage (Zhan \& Huang, 2013). This forced all enterprises to increase wage rates to attract migrant labor. Household enterprises were at a disadvantage as compared with large enterprises because of their limited scale and labor-intensive nature.

The increasing presence of large enterprises in the 2000s squeezed the space of household enterprises. ${ }^{38}$ They not only took resources such as land and labor but also controlled trade networks, particularly those to overseas markets. However, my investigation showed that large enterprises could not completely force household enterprises out of business even though they had an upper hand in the market. This was so because the community base of the latter provided them with protection and resources.

However, a change of local revenue regime since the late 1990s had severely weakened the dynamic. In the 1980s and 1990s, local governments in southern Jiangsu relied on collective enterprises, particularly township enterprises, for the main source of revenue. I call this TVE revenue regime. After collective enterprises were privatized, however, this source of revenue no longer existed and local governments started to grab and sell rural land for revenue. This can be called land revenue regime. ${ }^{39}$

The effect of the land revenue regime on the dynamic was almost the opposite of that of the TVE revenue regime. Under the latter, local governments preserved and promoted rural communities and enterprises. While local governments also took land from villages to establish township enterprises, this usually took place on a small scale and did not undermine the community base of rural enterprises. In addition, the government must compensate households with employment in township enterprises. Under 
the land revenue regime, however, the goal was to expropriate as much land as possible and sell it to large corporations and developers. It was often the case that the land of an entire village was expropriated. As a result, all households in the village would lose access to factories, vegetable plots and even houses.

As early as the 1980s, $\mathrm{Z}$ village was industrialized and no longer a village in conventional sense. However, it was still called a "village" because a village is different from an urban neighborhood in terms of state-sponsored rights and benefits. In a village, land is collectively owned, and village members (rural residents) are entitled to the usage rights of land and other natural resources within the boundary of the village. In urban neighborhoods, however, the state owns and controls land, and urban residents are excluded from land-related benefits, except that they could rent out their apartments.

Under the land revenue regime, the local government desired to turn villages into urban areas so that they could control the land. In addition, they colluded with real estate developers to push up housing prices so that land could be sold dear. In Changzhou prefecture, where W county is located, the amount of investment in real estate surged more than 11 times in 10 years (2001-2010), and the average housing price increased from less than 2,000 yuan per square meter to 6,437 yuan, more than tripled (Figure 3). Land prices also skyrocketed. In 2007, the government of W county sold land for 1.4 million yuan per mu on average; by 2010, it had jumped to 2.7 million (one US dollar was approximately 6.5 yuan in 2010). ${ }^{40}$ 41

\section{[Figure 3 here]}

By the time of my fieldwork, all villages between $\mathrm{Z}$ village and the city had been expropriated. The number of villages in Y township decreased from 37 in 2006 to 17 in 2010 . According to the township's plan, all remaining villages would be "urbanized" by 2015. ${ }^{42}$ In August 2010, the township government enclosed a third of Z village's land, and all houses and factories within would be demolished. It also indicated that it was a matter of time that the rest of the village would be expropriated. The change took place when I was in the village, thus it provided an opportunity of participant observation. 
The land revenue regime undermined the dynamic in two ways. First, it removed the community base, without which few village enterprises could survive. After land was expropriated, most of them could find neither a place to relocate nor suitable labor or necessary social resources.

Mr. Zou Yongqi, who was born in 1971, established a small plastic factory in 1992 with the help of his parents and money borrowed from his relatives. He married his wife, Ms. Liang Ying, in 1994, who was from a neighboring village. In the first 10 years, they used a part of their house as factory. In 2004, they leased one and half mu of village land at 5,000 yuan a year to build a new factory. Mr. Zou was in charge of technology and marketing while Ms. Liang was responsible for accounting and cooking meals for workers. When I interviewed them in their factory, they only hired three workers, down from eight workers when business was good. All workers were local, and they paid each of them 1,500 yuan a month plus lunch. They told me that the cost to hire migrant workers would be higher because they had to provide them with lodging. Both of them strongly opposed land expropriation and complained the living space of small enterprises like theirs was squeezed by government policy. Mr. Zou remarked, "Land expropriation is a nightmare to factory owners like us. In the past, the government would arrange another land if your land was expropriated. Now there is no such thing. Our business scale is too small to purchase land in other places... The government only supports large enterprises. No one, not even the village leaders, cares about small enterprises like us." 43

When I asked the owners of household enterprises whether their enterprises could be relocated to inland regions, their answer was also negative. The major reason was that relocation required a large investment, which most of them could not afford. In addition, these enterprises were closely attached to the local community and had access to hidden social and economic resources that were important to their success. Mr. Zou Xing and his wife, Ms. Qian Jihua, both in their 50s, ran a textile factory that employed about 20 workers when I interviewed them. Mr. Zou had a car accident in 2009, and his son, 37 years old, came home to help with the factory, but his daughter in law was working for a local electronic factory as an accountant. Both Mr. Zou and Ms. Qian were working for township enterprises in the 1980s, but they started a small textile factory in 1988 while retaining their collective jobs. In 1992, they closed the textile 
business and started making leather shoes, but it failed again in 2000. After that, they restarted a textile factory. Without enough start-up investment, they could not afford leasing land from the village. Thus they used a part of their own house and occupied a part of the river bank, which was next to their house, to build a factory. Mr. Zou told me, "I heard that a few enterprises relocated to northern Jiangsu and Anhui province, but they all came back at a loss. Wage rates there were low and electricity was cheap, but a lot of people came to make troubles. We are locals here, so no one could mess with us. "44

Second, land expropriation restricted market competition. As noted previously, the village boundary prevented community enterprises from being eliminated or taken over by large enterprises, and the existence of a large number of small enterprises increased the intensity of market competition. After land was expropriated, however, these village enterprises lost market competitiveness and even conditions for survival. The result was that a small number of large enterprises dominated the market and created a near oligopolistic structure. As small enterprises closed down one after another, industrial production in $\mathrm{W}$ county increasingly concentrated in large enterprises, which accounted for 88.0 percent of its industrial output in 2012, as compared with only 21.9 percent in $2000 .^{45}$ Real estate, which had become the most dynamic sector after the land revenue regime took hold, was also controlled by large developers.

Land expropriation undermined the dynamic and led to the closing of most community enterprises. As a result, previously industrialized villages were deindustrialized. Deindustrialization here refers not to the disappearing of industrial production in the region but to the closing of rural community enterprises in villages, which fundamentally changed the rural landscape. This process was a general trend in southern Jiangsu. Large enterprises, however, were less affected because they could move to government-built industrial parks or relocate elsewhere because they depend much less on community resources than small village enterprises do.

The weakening of the dynamic affected not only rural industry but also people's livelihood and welfare. As noted previously, an important feature of community enterprises was their broad involvement of community members, who-rich or poor, young or elder, strong or weak—could receive a share of the benefits generated from community assets. In addition, these enterprises did not exclude labor-semi- 
labor such as the elderly, the disabled and middle-aged women could all find employment in the village. However, land expropriation had done away with all of these.

The first group that bore the brunt is the owners of household enterprises. After their enterprises were closed, they would either become unemployed or picked up some odd jobs, particularly those in middle age. Mr. Zhang Chanhu, the owner of a shoe accessory factory, started the factory in 1992, and worked for a township enterprise making shoe accessories in the 1980s. Mr. Zhang's household had engaged in multiple businesses: he raised fish in the 1980s, and was also running a restaurant when I interviewed him. He was less concerned about land expropriation because he bought a piece of land in the neighboring township. However, he argued that land expropriation would affect most of the household enterprises. He discussed the situation of Mr. Zou Xing, his cousin, who I mentioned above.

"My cousin is now running dozens of power looms. It is easy for his family to make 100,000 yuan a year. Not a bad life, is it? However, if his land is expropriated, he could no longer run the factory. It is very difficult for him to find another job because he is already in his 50s. The only jobs he could find are gate keeping or street sweeping." 46

The second group is local rural laborers employed within the village. With the existence of a large number of household enterprises, their job opportunities were ample. Middle-aged men or women could work in relatives or fellow villagers' enterprises as accountants, shop-floor managers, loom maintainers, cooks, gate keepers, errand runners, etc. With the closing of these enterprises, these jobs would all disappear. It was unlikely for them to find jobs in large enterprises, which preferred young, collegeeducated or migrant workers.

The third group is middle- or low-income families, which accounted for at least 50 percent of the local population. The village community provided them with a low-cost living environment because of the benefits of the land. Moving to urban neighborhoods would greatly increase their cost of living. Mr. Xie Yuanxing, 47, was marketing shoes in the county town. He learnt shoe making when he was a teenager and running a small shoe factory in the 1980s and 1990s. He had been hired by a township enterprise as a 
technician in the 1980s, but only stayed for four years. Thus he did not see himself as a former TVE worker. He commented,

"Once land is expropriated, they (low-income families) can get a bare apartment from the government; to move in they have to spend tens of thousands on remodeling and decoration. After that, the cost will be even higher because they must buy everything they need. Now they use water from wells and grow vegetables themselves. The only thing they must buy for food is meat. ...In addition, many households own an old house, which they can rent to migrants for more than 1,000 yuan a month. Once land is expropriated, this source of income will also be gone." 47

Finally, land expropriation also affected migrant workers adversely. It was relatively easy for them to find new jobs in a situation of migrant labor shortage, but land expropriation made it difficult to find cheap housing. At least 1,000 migrants were renting houses in $\mathrm{Z}$ village. A family of three only paid 200300 yuan a month for a room. After these houses were torn down, however, migrant laborers had to find houses elsewhere, which had become increasingly difficult as more and more villages were being urbanized.

\section{THE OWNERSHIP DEBATE REVISIT AND FUTURE IMPLICATIONS}

Participants in the ownership debate focused on ownership, the market and/or the state. While these factors were certainly important, the case of $\mathrm{W}$ county showed that the role of community must also be considered because the success of most rural enterprises was attributed, at least partly, to their community base. Moreover, bringing in community sheds new light on both sides of the debate.

First of all, while both township and collective village enterprises were collectively owned, they were different in that the former were controlled by the government, whereas the latter belonged to the village community. This difference had not been given enough attention in the debate. For example, Oi attributed the development of TVEs to the positive role of local government. Her thesis was more applicable to township enterprises than to collective village enterprises because the performance of the latter was determined not by the government but by their communities. In addition, the community boundary 
protected village enterprises from the adverse impacts of external forces, thus they performed better than township enterprises in the 1990s.

Second, while collective village enterprises and private household enterprises differed in ownership, they were both located within the community and relied on community resources for success. In other words, they were both community enterprises. In addition, their relationship was not antagonistic as suggested by the ownership literature, but mutually dependent and symbiotic, particularly in the early reform period. As the case of $\mathrm{Z}$ village showed, nearly all owners of household enterprises had worked or were working in collective enterprises, and their private enterprises were highly dependent on money, skills (both technical and management) and market networks obtained from the latter. In the 1990s, these enterprise owners left collective enterprises in great numbers. Their exodus and competition partly contributed to the weakening of collective enterprises. Focusing on ownership might lead to the conclusion that collective enterprises were less competitive than private enterprises. Seeing the rural industry as a whole and historically, however, we should consider this a success rather than failure of collective enterprises because they nurtured a great number of private enterprises.

Third, the role of the Chinese state has undergone profound changes in the past three decades with regards to state-community relations. Under the TVE revenue regime in the 1980s and 1990s, the local state promoted the development of community enterprises, forming what Oi called local state corporatism, which "denotes a form of state-society relations where narrow interests within society are organized and integrated so as to achieve higher-order goals—-namely, stability and economic growth for the state and society as a whole" (1999: 12). Since the late 1990s, however, local governments started to rely on the land revenue regime, in which they expropriated and sold village land to large corporations and developers. As a result, the community base of rural enterprises was destroyed, forcing most of them to close. Under the land revenue regime, local state corporatism ceased to exist, and the local state to some extent turned into a predatory state, which pursued its own narrow interests at the expense of rural communities. 
Last but not least, the community-based market dynamic also sheds new light on community-market relations. Free market proponents stressed the importance of market competition and private ownership, and argued that the community boundary, within which property rights were ambiguous at best, obstructed market competition. However, the case of W county showed that the boundary did not obstruct but facilitate market competition because it kept a large number of community enterprises in the market. When the boundary was removed and village land became the private property of developers and large corporations in the recent decade, however, market competition was not enhanced but weakened, with industrial production and profitable real estate development concentrated in the hands of a small number of large companies and the local market turned into a near oligarchical structure.

In addition, a shift of focus from ownership to community could well explain post-privatization changes. Wen Tiejun, an expert of rural China, recently asked, "Why had the privatization of collective enterprises in southern Jiangsu not led to serious social unrest as it deprived millions of rural residents of job security and entitlements" (Wen, 2011)? This was puzzling as compared with waves of social protests launched by the workers of state-owned enterprises during the ownership reform in the late 1990s. Wen attributed it to the availability of welfare within villages. This study shows that it was not only community welfare but also economic opportunities generated from the community-based market dynamic that contributed to local rural residents' relative complacency. After the privatization, many local workers left collective enterprises, voluntarily or involuntarily, and started small enterprises of their own. These small enterprises provided abundant employment opportunities for local residents (as well as migrants).

By contrast, the recent large-scale land expropriation caused an unprecedented level of unrest in the area since the rural reform. Different from the privatization that kept the dynamic at least partially alive, land expropriation nearly destroyed it and led to the closing of community enterprises. During my stay in $\mathrm{Z}$ village, I felt intense anger that rural residents held toward the local government. A number of interviewees ${ }^{48}$ asked me why the communist party had become so unreasonable and robbed people without shame. Even Mr. Pan Yuanfang, the party sectary of the village, complained to me that local 
officials acted like bandits. The villagers were planning a protest, but it was eventually aborted due to the township government's intervention. However, in September and October of 2010, at least five protests were launched in W county. Unrest was also common in other parts of southern Jiangsu. In July 2010, a protest against land expropriation in Suzhou, another prefecture in southern Jiangsu, involved more than 10 thousand peasants. ${ }^{49}$ Nationally, it was reported that "mass incidents" due to land expropriation in recent years accounted for more than 50 percent of the total, amounting to tens of thousands a year (Chen, 2012: 13-14).

It is clear that the situation of local state corporatism described by Oi, in which the state and society pursued together "social stability and economic growth", no longer exists. A new model, which aims to grow economy and extract revenue by supporting large enterprises and developers and expropriating the assets of rural communities and small rural enterprises, has taken hold in China. This new model has been able to achieve rapid GDP growth in recent years. Yet it is highly unstable socially, with over a million of protests breaking out every year. It is an open question how far the Chinese state can push the new model in the future without reconsidering the importance of community enterprises to people's employment and livelihood.

\section{CONCLUSION}

This paper examined changes in Chinese rural industry for a relatively longer period and revisited the ownership debate. It has shown that the interaction between community and the market, which was missed in the debate, should be taken into account in understanding the rise and fall of rural enterprises, particularly changes in the recent decade after collective enterprises were privatized. Three tentative conclusions could be drawn from the analysis.

First, the community-based market dynamic, by combining seemingly contradictory community and market principles, was an important force driving the expansion of Chinese rural industry in the reform period. In the 1980s, village enterprises were relying on community resources for their success while at the same time actively participating in market competition. In the 1990s, collective village enterprises performed better than township enterprises because the dynamic helped them better fend off the adverse 
impacts of external politico-economic factors. In the early 2000s, the dynamic contributed to a temporary boom of village enterprises after privatization.

Second, the working of the dynamic had much to do with state policy and market conditions. In the early reform period, the Chinese state protected the land rights of villages, and market conditions were also conducive to community enterprises, leading to the emergence of the dynamic. After the mid-1990s, however, local governments sought to take these rights away and sell the land for revenue. In the meantime, large enterprises and developers moved to the countryside and worked with local governments to seize community resources. As a result, the dynamic lost its community basis and weakened.

Finally, the weakening of the dynamic produced serious socio-economic effects. Economically, previous industrial villages became deindustrialized and most rural enterprises were forced to close. Socially, a large number of rural residents lost industrial employment and livelihood security, setting off an unprecedented level of social unrest and undermining the social foundation of China's future economic development. 


\section{References}

Agrawal, A., \& Chhatre, A. (2006). Explaining success on the commons: Community forest governance in the Indian Himalaya. World Development, 34(1), 149-166.

Agrawal, A., \& Gibson, C. C. (1999). Enchantment and disenchantment: the role of community in natural resource conservation. World development, 27(4), 629-649.

Bardhan, P. (1993). Analytics of the institutions of informal cooperation in rural development. World

Development, 21(4), 633-639.

Blaikie, P. (2006). Is small really beautiful? Community-based natural resource management in Malawi and Botswana. World development, 34(11), 1942-1957.

Bramall, C. (2007). The Industrialization of Rural China. Oxford: Oxford University Press.

Burawoy, M. (1991). The Extended Case Method. In M. Burawoy (ed.), Ethnography Unbound (pp. 271-

187). Los Angles: University of California Press.

Burawoy, M. (2009). The extended case method: four countries, four decades, four great transformations, and one theoretical tradition. Berkeley \& Los Angeles: University of California Press.

Byrd, W. A., \& Lin, Q. (Eds.). (1990). China's rural industry: structure, development, and reform. Oxford: Oxford University Press

Byrd, W. A. \& N. Zhu (1990). Market interaction and industrial structure. In W. A. Byrd \& Q. Lin (eds.), China's rural industry: structure, development, and reform (85-111). Oxford: Oxford University Press.

Chang, C., McCall, B. P., \& Wang, Y. (2003). Incentive contracting versus ownership reforms: evidence from China's township and village enterprises. Journal of Comparative Economics, 31(3), 414-428.

Chen, G. (2012). Analysis and forecast of China's social development: 2012-2013. In Lu, X., P. Li \& G.

Chen (eds.), Bluebook of China's Society 2013 (pp.1-18). Beijing: Social Science Academic Press.

Dasgupta, A., \& Beard, V. A. (2007). Community driven development, collective action and elite capture in Indonesia. Development and Change,38(2), 229-249.

[DIFL] Decision-making Information for Leaders, (1999). Sanluan tunshi xiangqi lilun 20\% (Three arbitrary charges eat up 20 percent of profits of township enterprises). DIFL 47, 11.

Dong, X. Y. (1996). Two-tier land tenure system and sustained economic growth in post-1978 rural China. World Development, 24(5), 915-928. 
Fritzen, S. A. (2007). Can the design of community-driven development reduce the risk of elite capture? Evidence from Indonesia. World Development, 35(8), 1359-1375.

Gonzalez De La Rocha, M. (1994). The resources of poverty: Women and survival in a Mexican city. Oxford: Blackwell.

Gonzalez De La Rocha, M. (2001). From the resources of poverty to the poverty of resources? The erosion of a survival model. Latin American Perspectives, 72-100.

Hayami, Y. (1998). Community, Market, and State. in C. K. Eicher and J. M. Staatz (Eds.), International Agricultural Development (third edition) (pp.90-102). Baltimore: The Johns Hopkins University Press.

Huang, P. (1990). The Peasant Family and Rural Development in the Yangzi Delta, 1350-1988. Stanford: Stanford University Press.

Huang, Y. (2008). Capitalism with Chinese characteristics: Entrepreneurship and the state. Cambridge: Cambridge University Press.

Ife, J. W., \& Tesoriero, F. (2006). Community development: Community-based alternatives in an age of globalisation. Pearson Australia.

Jin, H., \& Qian, Y. (1998). Public versus private ownership of firms: evidence from rural China. Quarterly Journal of Economics 113(3), 773-808.

Kung, J. K. S., \& Lin, Y. M. (2007). The decline of township-and-village enterprises in China's economic transition. World Development, 35(4), 569-584.

Li, B. (2000). Jiannan Zaoqi Gongyehua: 1550-1850 [Early Industrialization in South China: 1550-1850]. Beijing: Social Sciences Academic Press.

Li, H., \& Rozelle, S. (2003). Privatizing rural China: insider privatization, innovative contracts and the performance of township enterprises. The China Quarterly, 176, 981-1005.

Li, T. M. (2002). Engaging simplifications: community-based resource management, market processes and state agendas in upland Southeast Asia. World development, 30(2), 265-283.

Lin, N. (1995). Local market socialism: Local corporatism in action in rural China. Theory and Society, 24(3), 301-354. 
Liu, S. (1995). Xiangzhengqiye fazhan zhong dui feizhengshi guanxi ziyuan de liyong (The role of informal social relations in the development of TVEs). Gaige (Reform) 8 (2), 62-68.

Lu, Y. (2000). Lu xiangzhen qiye de gaofuzai wenti [On the high level of debt among TVEs]. Studies on Township Enterprises, 6 (1), 5-8.

Luo, Y., Tan, J. J., \& Shenkar, O. (1998). Strategic responses to competitive pressure: The case of township and village enterprises in China. Asia Pacific Journal of Management, 15(1), 33-50.

Mansuri, G., \& Rao, V. (2004). Community-based and-driven development: A critical review. The World Bank Research Observer, 19(1), 1-39.

McMillan, J., \& Naughton, B. (1992). How to reform a planned economy: lessons from China. Oxford Review of Economic Policy, 8(1), 130-143.

[MOAC] Ministry of Agriculture of China (1997). China Township \& Village Enterprises Yearbook 1997. Beijing: China Statistical Press.

[MOAC] Ministry of Agriculture of China (1999). China Township \& Village Enterprises Yearbook 1999. Beijing: China Statistical Press.

[MOAC] Ministry of Agriculture of China (2003). China Township \& Village Enterprises Statistical Data 1978-2002. Beijing: China Statistical Press.

[MOAC] Ministry of Agriculture of China (2004). China Township \& Village Enterprises Statistical Yearbook 2004. Beijing: China Statistical Press.

[MOFC] Ministry of Finance of China (2014). Qunian maidi shouru chao 3.9 wanyiyuan [Income from Land sales exceeded to 3.9 trillion yuan last year]. Xinjingbao (The Beijing News) (July 15, 2014), page A07.

Naughton, B. (1995). Growing out of the plan: Chinese economic reform, 1978-1993. Cambridge:

Cambridge University Press.

[NBSC] National Bureau of Statistics of China (1986). China statistical yearbook 1986. Beijing: China Statistics Press. 
Nee, V. (1989). A theory of market transition: From redistribution to markets in state socialism. American Sociological Review, 663-681

Nee, V. (1992). Organizational dynamics of market transition: hybrid forms, property rights, and mixed economy in China. Administrative science quarterly, 37(1), 1-27.

North, D. C., \& Thomas, R. P. (1973). The rise of the Western world: a new economic history. Cambridge, UK: Cambridge University Press.

Oi, J. C. (1992). Fiscal reform and the economic foundations of local state corporatism in China. World Politics, 45(01), 99-126.

Oi, J. C. (1999). Rural China takes off: Institutional foundations of economic reform. Berkeley \& Los Angeles: University of California Press.

Oi, J. C., \& Walder, A. G. (Eds.). (1999). Property rights and economic reform in China. Stanford, CA: Stanford University Press.

Ostrom, E. (1990). Governing the commons: The evolution of institutions for collective action. Cambridge university press.

Park, A., \& Shen, M. (2003). Joint liability lending and the rise and fall of China's township and village enterprises. Journal of Development Economics,71(2), 497-531.

Pei, X. (2002). The contribution of collective landownership to China's economic transition and rural industrialization: a resource allocation Model. Modern China, 28(3), 279-314.

Peng, Y. (2004). Kinship Networks and Entrepreneurs in China’s Transitional Economy1. American Journal of Sociology, 109(5), 1045-1074.

Portes, A., \& Landolt, P. (2000). Social capital: promise and pitfalls of its role in development. Journal of Latin American Studies, 32(02), 529-547.

Putterman, L. (1997). On the past and future of China's township and village-owned enterprises. World Development, 25(10), 1639-1655.

Qian, Y. (2000). The process of China's market transition (1978-1998): the evolutionary, historical, and comparative perspectives. Journal of Institutional and Theoretical Economics, 151-171. 
Rawski, T. G. (1994). Chinese industrial reform: accomplishments, prospects, and implications. The American Economic Review, 8 (2), 271-275.

Region, G. Y. R. (2004). Productivity Effects of TVE Privatization. Governance, regulation, and privatization in the Asia-Pacific Region, 231.

Shao, Y. (2010). Guanyu tudi caizheng yu caishui tizhi gaige wenti zongshu [a review on land revenue and the issues of the fiscal and tax reform]. Review of Economic Research (China), 32 (24), 36-45.

Shirley, M. M., \& Walsh, P. (2001). Public vs. private ownership: the current state of the debate. World Bank Policy Research Working Paper, No. 2420. Washington, D.C.: World Bank.

Sonobe, T. \& K. Otsuka (2004). Productivity Effects of TVE privatization: the case study of garment and metal-casting enterprises in the Greater Yangtze River Region. In T. Ito \& A. O. Krueger (Eds.), Governance, regulation, and privatization in the Asia-Pacific Region (pp.231-250). Chicago: University of Chicago Press.

Van Velsen, J. (1960). Labor migration as a positive factor in the continuity of Tonga tribal society. Economic Development and Cultural Change, 8(3), 265-278.

Van Velsen, J. (1968). The extended-case method and situational analysis. In A.L.Epstein (ed.), The Craft of Social Anthropology (pp.129-149). London and New York: Tavistock Pub lication.

Walder, A. G. (1995). Local governments as industrial firms: an organizational analysis of China's transitional economy. American Journal of sociology, 101(2), 263-301.

Wen, T. (2011). Jiedu Sunan (Explaining Sunan). Suzhou, Jiangsu province: Suzhou daxue chubanshe. Whiting, S. H. (1996). Contract Incentives and Market Discipline in China's Rural Indus trial Sector. In J. McMillan \& B. Naughton (eds.), Reforming Asian Socialism, The Growth of Market Institutions (pp.63110). Ann Arbor: The University of Michigan Press.

Woolcock, M., \& Narayan, D. (2000). Social capital: Implications for development theory, research, and policy. The world bank research observer,15(2), 225-249.

Ye, D., Zhang, Y. \& Wu, D. (1995). Xinyilun de zaozhen yundong (A new round of town-making movements). Shehuixue yanjiu (sociological studies) 10 (2), 17-22. 
Yin, X. (2008). Ershi shiji sunan nongye yu nongcun bianqian yanjiu (Transition of agriculture and countryside in southern Jiangsu province in the 20th century). Beijing: Sanxia chubanshe.

Zhan, S. (2011). What determines migrant workers' life chances in contemporary China? Hukou, social exclusion, and the market. Modern china,37 (3), 243-285.

Zhan, S., \& Huang, L. (2013). Rural roots of current migrant labor shortage in China: development and labor empowerment in a situation of incomplete proletarianization. Studies in comparative international development, $48(1), 81-111$.

Zhang, J. (2005). State power, elite relations and the politics of privatization in Chinese rural industry. Sociological studies (China), 20 (5), 92-124.

Zhang, X., \& Yuan, P. (2003). zhongguo xiangzhen qiye chanquan gaige beiwanglu [Memos on TVEs' ownership reform in China]. Beijing: Social Science Academic Press.

Zhou, H. (Ed.). (1994). Suxichang fazhan baogao (A report on the development of Suzhou-WuxiChangzhou region). Beijing: People's Daily Press. 
${ }^{1}$ The increase in academic attention was also due to the remarkable performance of Chinese rural industry. Between 1978 and 1991, the gross rural industrial output grew 23.0 percent a year on average (MOAC, 2003: 9). Scholars participated in the debate include but not limited to Hehui Jin \& Yingyi Qian (1998), Victor Nee (1992), Jean C. Oi (1992; 1999), Thomas G. Rawski (1994) and Andrew G. Walder (1995).

${ }^{2}$ As a result of privatization, the number of collective enterprises in China plummeted from 1.1 million in 1998 to 0.3 million in 2003. It was even more drastic in Jiangsu province, which was once a flagship province for collective enterprises, with the number down from 77.6 thousand to 5.2 thousand over the same period (MOAC, 1999: 11-112; 2004: 102-105).

${ }^{3}$ For example, a number of new concepts and frameworks were created during the debate, including but not limited to gradualism (McMillan \& Naughton, 1992; Rawski, 1994), local state corporatism (Oi, 1992; 1999) and (local) market socialism (Lin, 1995).

${ }^{4}$ Due to the sensitivity of some issues discussed in this paper, I anonymized places below the prefectural level to protect my interviewees.

${ }^{5}$ Industrial production continues to exist: it is now concentrated in a few industrial parks where only very large industrial enterprises are permitted entrance.

${ }^{6}$ For a useful account of the two sides in the debate, please see Oi \& Walder eds. (1999).

${ }^{7}$ Other scholars advanced similar arguments, see Chang \& Wang (1994: 443-446); Jin \& Qian (1998).

${ }^{8}$ In China, the hierarchy of jurisdictions below the central government consists of the following five levels in an descending order: province (sheng) (it is called an autonomous region (zizhiqu) if it is an ethnic area, for example, Xinjiang, and four centrally-governed municipalities (zhixiashi) also position at this level, for example, Beijing), prefecture/municipality (shi), county (xian), township (xiang), and village (cun). Township is the lowest level of government, and village is a self-governing unit. A higher level of jurisdiction usually consists of a few to more than a dozen of jurisdictions at the subsequent lower level. 
${ }^{9}$ The Sunan model featured the prevalence of collective ownership and was contrasted with the Wenzhou model, which was characterized by private ownership. However, the dominance of collective ownership, rather than the existence of private ownership, was considered a unique characteristic of Chinese rural industry during the early reform period.

${ }^{10}$ Townships and villages were called communes and brigades respectively in the Mao period.

${ }^{11}$ Other nonfarm activities undertaken prior to 1949 included tailoring, haircutting, carpentering, house building, farm implement making, silkworm breeding, etc.

${ }^{12}$ For a detailed discussion of this method, please see van Velsen (1960; 1968); Burawoy (1991; 2009: 1-18).

${ }^{13}$ These forums include dzh.mop.com; tieba.baidu.com ; www.hualongxiang.com; bbs.cz001.com.cn.

${ }^{14}$ For a comprehensive account of rural industrialization in the Mao period, please see Bramall (2007).

${ }^{15}$ As a result, the grain output fell by 20 percent in the 1980s. However, it was maintained around 600 metric tons a year, sufficient to feed 1500 people in $\mathrm{Z}$ village. The reason was probably that peasants could take care of farming after they finished work in factories, which were either in the village or nearby.

${ }^{16}$ Source: W county's 1987 industrial census.

${ }^{17}$ Interview No. 27, October 15, 2010.

${ }^{18}$ Interview No. 7, September 4, 2010. The names of all interviewees are fictitious.

${ }^{19}$ In 1985, the average monthly rate of wages in urban industrial enterprises was 92.6 yuan (NBSC, 1986: 656), whereas the average wage rate in TVEs was about 30-40 yuan, according to my fieldwork. In addition, urban industrial enterprises had to provide housing for their workers.

${ }^{20}$ Three community resources were particularly important: land, labor and social networks. Some scholars also pointed out another resource, collective capital, because collectives provided initial start-up funds for rural enterprises, particularly in the early 1980s. Please see Oi (1999).

${ }^{21}$ Here it shows a key difference between household and collective village enterprises in that the former received less support than the latter from the village authority, which was able to pool community resources such as land and 
money together, and sometimes able to get loans from banks. Household enterprises used community resources mainly based on their entitlements and social networks.

${ }^{22}$ This may have decreased average labor productivity, but taking the community as a whole it reduced the costs of labor reproduction and increased community welfare.

${ }^{23}$ Interview No.28, October 15, 2010.

${ }^{24}$ Please see Liu (1995) and Peng (2004).

${ }^{25}$ According to $\mathrm{Z}$ village's gazetteer and my interviews with village officials, the village had tried more than more than 10 enterprises in the 1980s, but only six enterprises lasted to the 1990s. Many households would establish another enterprise after an earlier venture failed. The examples include Zou Xing's household and Zhang Chanhu's household that I will discuss below.

${ }^{26}$ Interview No. 19, September 12, 2010.

${ }^{27}$ In addition, the government of $\mathrm{W}$ county encouraged spreading industrial jobs among poor peasants. A county policy in 1985 demanded that the local authority must offer poor households employment in TVEs. This policy gave poor peasants an opportunity to learn industrial skills and increase household income, thus having narrowed inequality within the village and enhanced their sense of community.

${ }^{28}$ According to W county's annual reports on rural industry, the county and township governments allocated a large fund each year in the 1980s and 1990s to train TVE workers.

${ }^{29}$ The statistic probably excluded many household factories, which were often not on official books.

${ }^{30} \mathrm{~W}$ county government's 2001 annual report.

${ }^{31}$ Source of the document: W county Archival Bureau.

${ }^{32}$ Source of the data: W county Archival Bureau.

${ }^{33}$ The basic tax rate for TVEs was about 20-30 percent of their profits (Naughton, 1995). In the 1990s, however, township enterprises were increasingly subjected to the government's extra changes. In 1999, six central government agencies sent out a team to nine provinces to investigate the burden of township enterprises, and found that all kinds of extra charges added up to at least 20 percent of the profits of township enterprises (DIFL, 1999).

${ }^{34}$ Date source: land lease records kept in Z village's archives. 
${ }^{35}$ The amount of compensation was based the number of years he or she had worked in collective enterprises. One year of work was compensated for one month's salary at the local average rate.

${ }^{36}$ Sources: Y township's 2001 industrial census and 2004 economic census. My local collaborator's investigation in 2006 also showed the rapid expansion of household enterprises in W county.

${ }^{37}$ Interview No. 21, September 12, 2010.

${ }^{38}$ Most of the large enterprises were of urban or foreign origin, and a small number of them were privatized collective enterprises.

${ }^{39}$ The emergence of the land revenue regime also had something to do with the fiscal reform in 1994, which increased the share of the central government in tax revenue but allowed local governments to keep the revenue from land sales. For a detailed account, please see Shao (2010).

${ }^{40}$ W county's annual statistical reports 2007-2011.

${ }^{41}$ Strictly speaking, the government leased rather than sold the land to developers. After a land transaction is made, the government will maintain land ownership but lease the land to the developer for 70 years of use, and the developer sells real estate, which is built on the land, to private owners. However, private owners regard their houses/apartments as private property, and it is unlikely for the government to seize private houses/apartments after 70 years of use. In this context, lease is equivalent to sale. And using "sale" (mai in Chinese) rather than "lease" ( $z u$ in Chinese) is also in line with the popular description of such land transactions in China.

${ }^{42}$ The land revenue regime is still firmly in place. The Ministry of Finance of China recently released that local governments' land revenue reached up to 3.9 trillion yuan in 2013, making up more than 60 percent of the local revenue (MOFC, 2014).

${ }^{43}$ Interviews No. 52 and No.53, October 26, 2010.

${ }^{44}$ Interview No. 3, September 3, 2010.

${ }^{45}$ Source: W county's yearbooks 2001 and 2013.

${ }^{46}$ Interview No.45, October 21, 2010. 
${ }^{47}$ Interview No. 51, October 26, 2010.

${ }^{48}$ These interviewees include aforementioned Mr. Zou Xing; Ms. Qian Jihua; Mr. Zou Yongqi, as well as Ms. Zhang Qun, who was working for the village committee but retired when I interviewed her; Mr. Wu Zhaohu, who was working for a township enterprise and retired when I interviewed him; Mr. Zhang Nieping, who was working for the privatized village shoe accessory at the time of interview; Ms. Xu Ying, who worked for a township textile factory and was running a small shop in her own house at the time of interview; Ms. Zhang Boying, who was still working for a private textile factory in her 60s because of family difficulties; Mr. Yao Jian, who was running a shower house for migrants when I interviewed him.

${ }^{49}$ Caijingwang, July 19, 2010. Retrieved from http://www.caijing.com.cn/2010-07-19/110481889.html. 


\section{Tables}

Table 1 Township \& Village enterprises in China in 1996

\begin{tabular}{|l|l|l|l|}
\hline Enterprise type & $\begin{array}{l}\text { Township } \\
\text { enterprises }\end{array}$ & $\begin{array}{l}\text { Collective } \\
\text { village } \\
\text { enterprises }\end{array}$ & $\begin{array}{l}\text { Household enterprises } \\
\text { (including those owned } \\
\text { by multiple household) }\end{array}$ \\
\hline Number (thousand) & 410 & 1,140 & 21,810 \\
\hline Workers employed (million) & 29.6 & 30.0 & 75.6 \\
\hline $\begin{array}{r}\text { Value added of all rural enterprise } \\
\text { (billion yuan) }\end{array}$ & 512.8 & 513.0 & 740.1 \\
\hline $\begin{array}{r}\text { Value added of industrial enterprises } \\
\text { (billion yuan) }\end{array}$ & 408.0 & 411.5 & 443.2 \\
\hline
\end{tabular}

Source: MOAC (1997): 121. 


\section{Figures}

Figure 1 Location of Changzhou prefecture
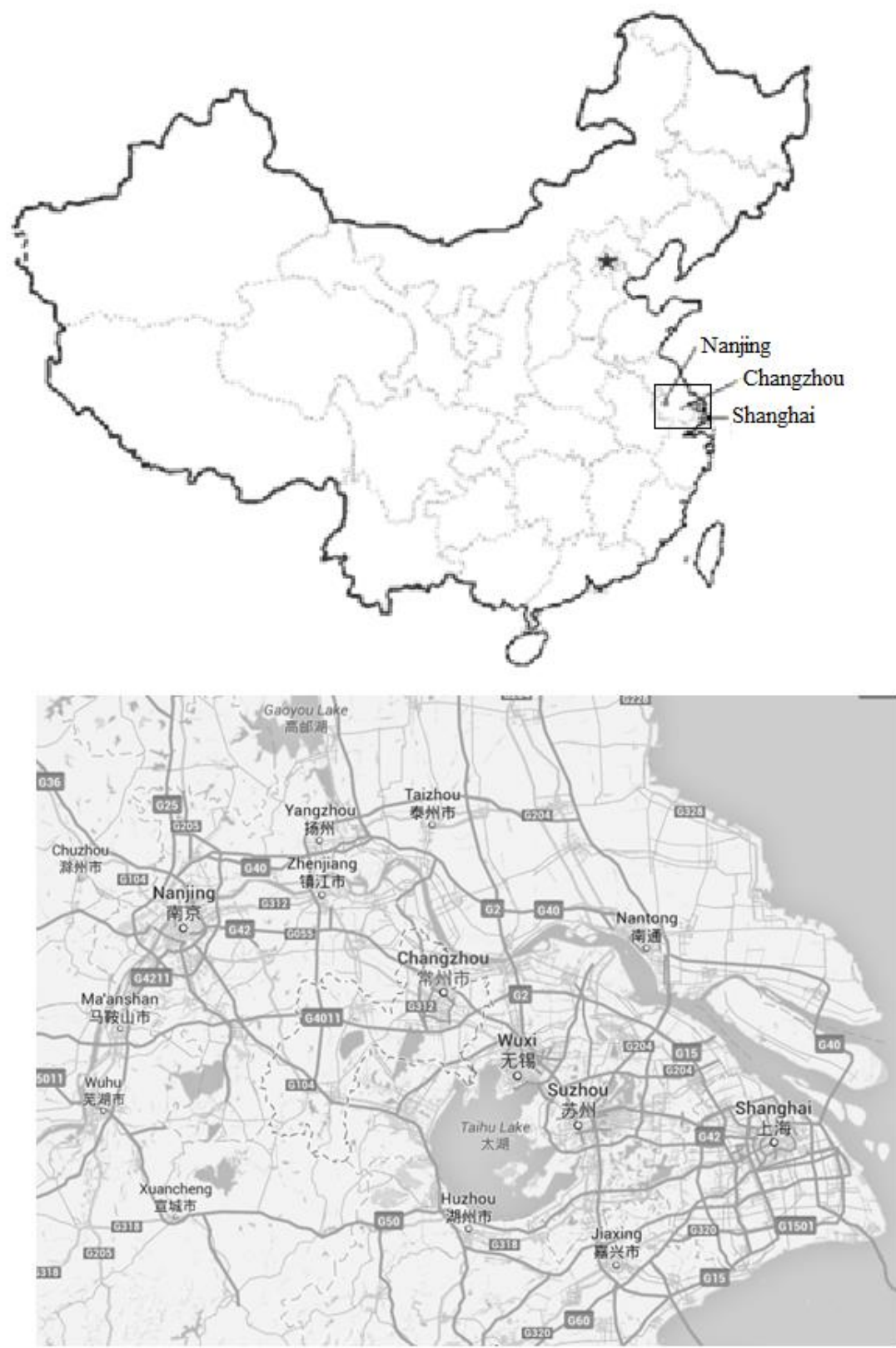

Note: The second map is a screenshot of the Googl Map. 
Figure 2 Number of workers employed in private and collective enterprises: 1985-1998

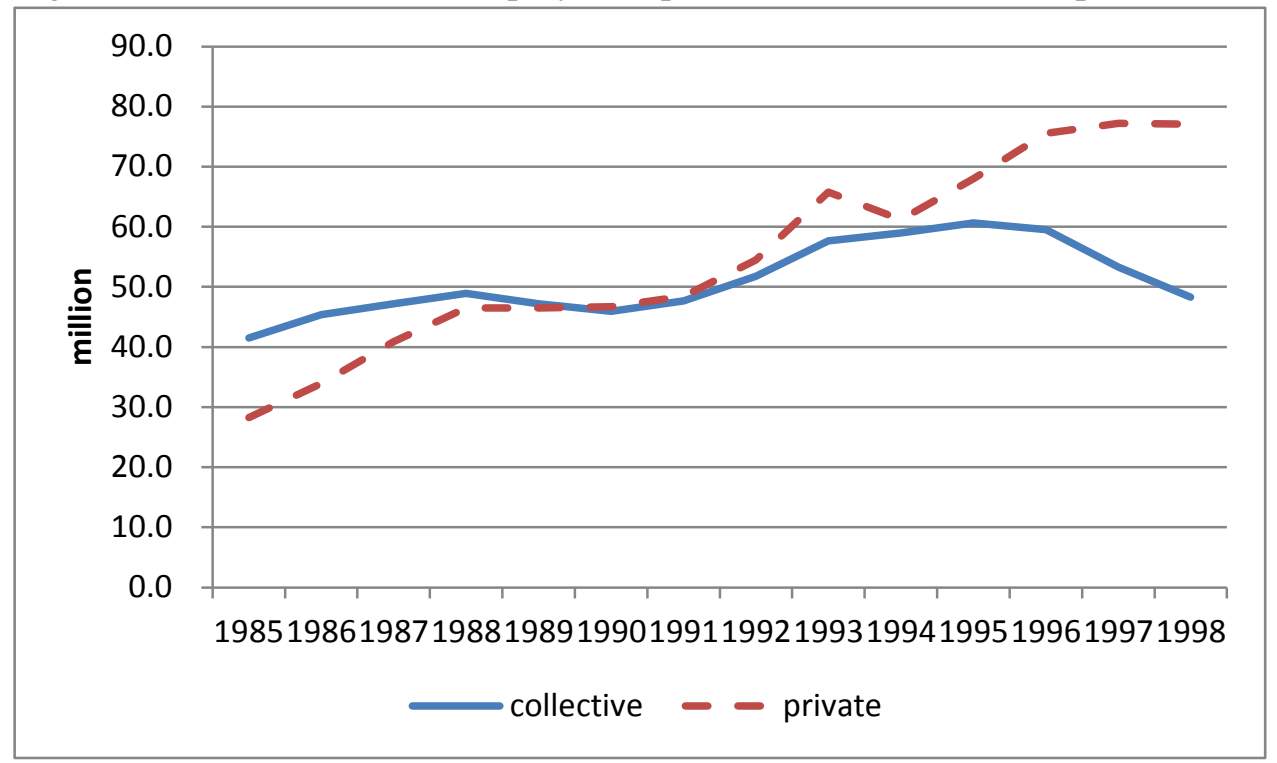

Data source: MOAC (2003: 6)

Figure 3 Real estate investment and average housing price in Changzhou: 2001-2010

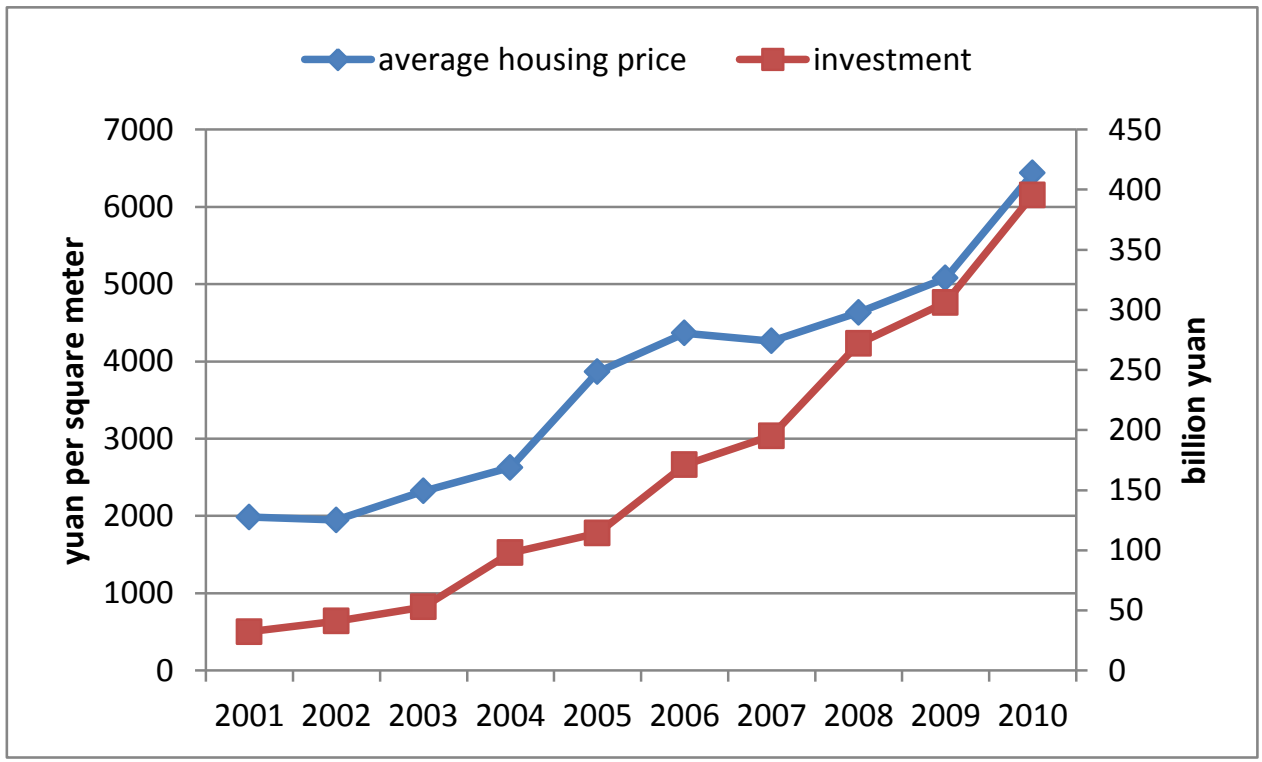

Data source: Changzhou statistical yearbook 2001-2011. 
From Privatization to Deindustrialization:

Implications of Chinese Rural Industry and the Ownership Debate Revisited

Shaohua Zhan

Nanyang Technological University, Singapore

Mailing address: HSS-05-38, 14 Nanyang Drive, Singapore 637332

Email: zhansh@jhu.edu; shzhan@ntu.edu.sg

Tel: (65) 6790-4739 (office) 
Acknowledgement

I wish to express my gratitude to Yihong Jin for her help on my fieldwork. I also benefited enormously from comments and suggestions from Joel Andreas, Gaye Christoffersen, Patrick Heller, Lingli Huang, Michael Levien, Beverly Silver and Min Zhou. An earlier version was presented at the workshop Agrarian Development in China: Legacies and Prospects (Johns Hopkins University, November 1, 2013). I am most grateful to three anonymous reviewers who helped me improve the paper considerably. The research was funded by a dissertation improvement grant from the National Science Foundation (USA). 